\title{
PEDOCHRONOLOGY AND DEVELOPMENT OF PEAT BOG IN THE ENVIRONMENTAL PROTECTION AREA PAU-DE- FRUTA - DIAMANTINA, BRAZIL ${ }^{(1)}$
}

\author{
José Ricardo da Rocha Campos ${ }^{(2)}$, Alexandre Christófaro Silva ${ }^{(3)}$, Leandro Lara \\ Vasconcellos $^{(4)}$, Daniel Valladão Silva ${ }^{(5)}$, Rafael Vitor Romão ${ }^{(4)}$, Enilson de \\ Barros Silva $^{(6)}$ \& Paulo Henrique Grazziotti ${ }^{(3)}$
}

\begin{abstract}
SUMMARY
In the region of the Serra do Espinhaço Meridional, peat bog is formed in hydromorphic environments developed in sunken areas on the plain surfaces with vegetation adapted to hydromorphic conditions, favoring the accumulation and preservation of organic matter. This pedoenvironment is developed on the regionally predominant quartzite rocks. Peat bog in the Environmental Protection Area - APA Pau-de-Fruta, located in the watershed of Córrego das Pedras, Diamantina,Brazil, was mapped and three representative profiles were morphologically characterized and sampled for physical, chemical and microbiological analyses. The organic matter was fractionated into fulvic acid (FA), humic acids (HA) and humin (H). Two profiles were sampled to determine the radiocarbon age and $\delta^{13} \mathrm{C}$. The structural organization of the three profiles is homogeneous. The first two layers consist of fibric, the two subsequent of hemic and the four deepest of sapric peat, showing that organic matter decomposition advances with depth and that the influence of mineral materials in deeper layers is greater. Physical properties were homogeneous in the profiles, but varied in the sampled layers. Chemical properties were similar in the layers, but the Ca content, sum of bases and base saturation differed between profiles. Contents of $\mathbf{H}$ predominated in the more soluble organic matter fractions and were accumulated at a higher rate in the surface and deeper layers, while HA levels were higher in the intermediate and FA in the deeper layers. Microbial activity did not vary among profiles and was highest in the surface layers, decreasing with depth. From the
\end{abstract}

\footnotetext{
(1) Part of the Master of Science Dissertation in Vegetable Production presented by the first author at the Universidade Federal dos Vales do Jequitinhonha e Mucuri - UFVJM. Received in September 2009 approved in October 2010.

(2) Departamento de Ciência do Solo - Esalq/USP. Rua da Glória 187, CEP 39100-000 Diamantina (MG). E-mail: jricardo28@yahoo.com.br

(3) Departamento de Engenharia Florestal, UFVJM. E-mails: christo@jknet.com.br; grazziotti@yahoo.com.br

(4) Scientific Initiation student- UFVJM. E-mails: rafaelromaov@yahoo.com.br; vasconcelos@yahoo.com.br.

(5) Masters student in Vegetable Production - UFVJM. E-mail: danielvaladaos@yahoo.com.br

(6) Departamento de Agronomia - UFVJM. E-mail: ebsilva@ufvjm.edu.br
} 
results of radiocarbon dating and isotope analysis, it was inferred that bog formation began about 20 thousand years ago and that the vegetation of the area had not changed significantly since then.

Index terms: Organosols, soil organic matter, humic substances, microbial activity, radiocarbon dating, $\delta^{13} \mathrm{C}$.

\title{
RESUMO: PEDOCRONOLOGIA E DESENVOLVIMENTO DA TURFEIRADA ÁREA DE PROTEÇÃO AMBIENTAL PAU-DE-FRUTA, DIAMANTINA - MG
}

\begin{abstract}
Na região da Serra do Espinhaço Meridional, a formação de ambientes hidromórficos em áreas deprimidas de superfícies de aplainamento, aliada à ocorrência de uma vegetação adaptada à condição de hidromorfismo, favorece o acúmulo e a preservação de matéria orgânica, formando turfeiras. Esse pedoambiente desenvolve-se sobre rochas quartzíticas, predominantes na região. A turfeira da Área de Proteção Ambiental - APA Pau-de-Fruta, localizada na microbacia do Córrego das Pedras, municipio de Diamantina-MG, foi mapeada e três perfis representativos foram caracterizados morfologicamente e amostrados para caracterização física, química e microbiológica. A matéria orgânica foi fracionada em ácidos fúlvicos $(A F)$, ácidos húmicos $(A H)$ e humina $(H)$. Dois perfis tiveram amostras coletadas para determinação da idade radiocarbônica e do $\delta^{13} C$. Os três perfis apresentam organização estrutural homogênea, sendo as duas primeiras camadas fíbricas, as duas subsequentes hêmicas e as quatro mais profundas sápricas, evidenciando que o estádio de decomposição da matéria orgânica avança com a profundidade e as camadas mais profundas apresentam maior influência do material mineral. Os atributos físicos foram homogêneos entre os perfis, mas variaram entre as camadas amostradas. Os atributos químicos foram semelhantes entre as camadas, porém o teor de Ca, a soma de bases e a saturação por bases diferiram entre os perfis. Os teores de H predominaram sobre as frações mais solúveis da matéria orgânica e se acumularam em maior proporção nas camadas mais superficiais e nas mais profundas, enquanto os AH foram mais elevados nas camadas intermediárias e os AF nas camadas mais profundas. A atividade microbiológica não variou entre os perfis e foi mais elevada nas camadas superficiais, diminuindo com a profundidade. A partir dos resultados das datações radiocarbônicas e da composição isotópica, inferiu-se que a turfeira começou a ser formada há cerca de 20 mil anos e que, desde então, a cobertura vegetal da área não sofreu variações significativas.
\end{abstract}

Termos de indexação: Organossolo, matéria orgânica do solo, substâncias húmicas, atividade microbiológica, datações radiocarbônicas, $\delta^{13} \mathrm{C}$.

\section{INTRODUCTION}

Peat bogs are pedoenvironments formed by successive accumulation of plant remains at sites under conditions where the activity of microbial decomposers is inhibited by excessive moisture, low $\mathrm{pH}$, lack of oxygen and warm temperatures.

Worldwide, it is estimated that an area of about 400 million ha is covered with peat bog, equivalent to $3 \%$ of the Earth's surface. Most of this area, about 350 million ha, is in the Northern Hemisphere and between 30.5 and 45.9 million in the Tropics (Rieley et al., 2008). In Brazil, it is estimated that peat bogs cover approximately $611,883 \mathrm{ha}$, i.e., around $0.07 \%$ of the national territory (Valladares, 2003).

In the Espinhaço, which is the only Brazilian mountain range and crosses the states of Minas
Gerais, Bahia and Piauí (Silva et al., 2005), peat is associated with other types of shallow and sandy soils. Silva (2004a,b,c; 2005) mapped 112,233 ha of land in four protected areas of the mountain range called Serra do Espinhaço Meridional (SdEM), of which 12,814 ha correspond to mapping units where Organosols (peatlands) occur in association with other soils.

In tropical peat bogs in high-altitude environments with mild climate, Augustin et al. (1994) and Silva et al. (2004) detected radiocarbon ages of more than 30,000 years before present (BP). In contrast, the ages of peat bogs in temperate regions were below 16,000 years BP (Gorham \& Janssens, 1992; Martinez-Cortizas et al., 1997, 1999; Shotyk et al., 1998; Jedrysek et al., 2003), once C accumulation in these areas was affected by glaciations at the end of the Pleistocene period and beginning of the Holocene. 
The soil organic matter (SOM), consisting mainly of decomposed vegetation of this area, is an important evidence of possible variations in climate and vegetation in the last thousands of years (Gouveia et al., 1997). Radiocarbon dating and stable isotope $\delta^{13} \mathrm{C}$ can provide this information. The former provides information regarding the succession of events, while the latter identifies the origin of SOM, given that plants can be separated, according to their photosynthetic cycle, into $\mathrm{C}_{3}, \mathrm{C}_{4}$ and $\mathrm{CAM}$. The species can be separated in $\mathrm{C}_{3}$ species with $\delta^{13} \mathrm{C}$ values ranging between - 24 and $-3 \%, \mathrm{C}_{4}$ species with values between -11 and $-15 \%$ and CAM species, between -11 and -29\%o (Martinelli et al., 2009). Boutton (1991) established $\delta^{13} \mathrm{C}$ values ranging from -10 to $-28 \%$ for CAM species.

Peat bogs grow vertically and their growth rate can be calculated annually. Pontevedra-Pombal (2002) studied peat bogs in Galicia and found an annual growth rate of $0.20-0.70 \mathrm{~mm}^{-1}$ year $^{-1}$, with an average of $0.44 \mathrm{~mm}_{\text {year }}{ }^{-1}$. In peat bogs in Finland, Tolonen (1979) found a growth rate of 0.60 $0.75 \mathrm{~mm}$ year $^{-1}$ and Gorham (1991) in Canada about $0.48 \mathrm{~mm}$ year ${ }^{-1}$.

In the region of Diamantina, state of Minas Gerais, peat bogs are found in the Environmental Protection Area Pau-de-Fruta (EPA Pau-de-Fruta) with predominantly quartzitic lithology, mild climate, where a typical vegetation of montane grasslands grows, interspersed with savannah fragments (capões). In this pedoenvironment, excess moisture associated with low nutrient content, mild climate and vegetation adapted to the hydromorphic conditions favor the accumulation and preservation of organic matter.

The aim of this study was to analyze the physical, chemical and microbiological characteristics of three peat profiles in EPA Pau-de-Fruta and to determine their chronology and variations in vegetation cover as well as carbon accumulation and annual growth rates.

\section{MATERIALS AND METHODS}

\section{Location and characterization of the study area}

The peat bog studied covers 81.75 ha of the EPA Pau-de-Fruta in a watershed of 686 ha (Figure 1), which corresponds to $11.9 \%$ of the area. The source of the river Córrego das Pedras is in this area and supplies the population of Diamantina, located $6 \mathrm{~km}$ away, with water (Campos, 2009).

The area is embedded in the SdEM at an average altitude of $1,366 \mathrm{~m}$. This is an area with evidence of quartzite associated with the occurrence of hematitic phyllites and marshes in hydro-morphic depressions with water springs, where peat bogs are overlying fluvial or colluvial sands and gravels (Almeida Abreu, 1989; Saadi, 1995).

The temperatures are mild for most of the year, with an average of $19.0^{\circ} \mathrm{C}$ and monthly averages ranging from $16.1{ }^{\circ} \mathrm{C}$ in the coldest (July) to $21.3^{\circ} \mathrm{C}$ in the warmest month (January). The average rainfall is $1,351 \mathrm{~mm}$ (Neves et al., 2005).

The predominant vegetation of the study area is montane grassland, characterized by the predominance of herbaceous species such as Asteraceae, Melastomataceae, Eriocaulaceae, and Xyridaceae (Silva et al., 2005). A few savannah fragments (capões) of Cerrado vegetation with shrub and tree species are also found in the area (Ribeiro \& Walter, 1998).

\section{Site selection, profile description and sampling}

The entire area was inspected and, after 400 borings, three sites were selected for description and sampling of representative peat profiles (Figure 1). In the highest part of the peat bog, samples were collected from an extra profile (P4) (Figure 1) for radiocarbon dating. The classification, coordinates (UTM) and profile elevation are presented in table 1.

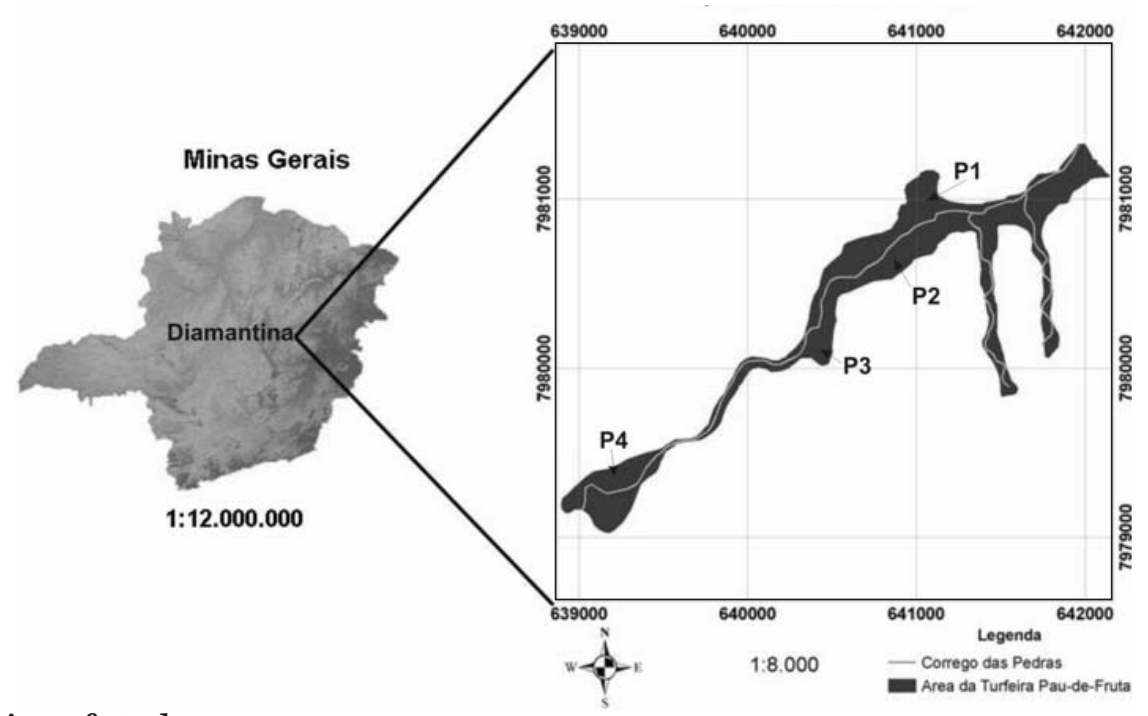

Figure 1. Location of study area. 
Table 1. Location, depth, elevation and classification of the sampled profiles

\begin{tabular}{|c|c|c|c|c|c|c|}
\hline \multirow{2}{*}{ Profile } & \multirow{2}{*}{ Coordinates } & \multirow{2}{*}{ UTM } & \multirow{2}{*}{ Depth } & \multirow{2}{*}{ Elevation } & \multicolumn{2}{|c|}{ Classification } \\
\hline & & & & & Embrapa, 2006 & Soil Taxonomy (1999) \\
\hline & $\mathrm{S}$ & $\mathrm{W}$ & $\mathrm{cm}$ & $\mathrm{m}$ & & \\
\hline 1 & 640455 & 7980139 & 216 & 1355 & Organossolo Háplico Sáprico típico & Typic Haplosaprists \\
\hline 2 & 640835 & 7980614 & 216 & 1352 & Organossolo Háplico Sáprico típico & Typic Haplosaprists \\
\hline 3 & 641435 & 7980943 & 216 & 1350 & Organossolo Háplico Sáprico típico & Typic Haplosaprists \\
\hline 4 & 639167 & 7979340 & 180 & 1360 & Organossolo Háplico Sáprico típico & Typic Haplosaprists \\
\hline
\end{tabular}

Samples were collected by inserting an open PVC tube (length $230 \mathrm{~cm}$, diameter $5.0 \mathrm{~cm}$ ) through the peat bog down to the basal substrate. The tube was immediately covered and pulled back to the surface where it was placed horizontally. The lid was removed and instead, a wooden tampion (length $20 \mathrm{~cm}$, diameter $4.5 \mathrm{~cm}$ ) was inserted and slowly pushed through the pipe with an iron rod.

Samples were collected every $27 \mathrm{~cm}$, taking into account material homogeneity, down to the interface with the basal substrate, at a depth of $215 \mathrm{~cm}$.

\section{Physical characterization}

All samples from the profiles 1, 2 and 3, Organosol were characterized, as described by Lyn et al. (1974) and cited by Embrapa (2006), for: the rubbed fiber content (RF); mineral material (MM); color detection by the sodium pyrophosphate method; organic matter decomposition stage, according to von Post; soil density (Ds); and organic matter density (OMd).

\section{Chemical characterization}

In the profiles 1,2 and 3 , the $\mathrm{pH}$ in water was determined and the $\mathrm{K}$ content analyzed by a flame photometer after extraction with $\mathrm{HCl}\left(0.05 \mathrm{~mol} \mathrm{~L}^{-1}\right)$ and $\mathrm{H}_{2} \mathrm{SO}_{4}\left(0.0125 \mathrm{~mol} \mathrm{~L}^{-1}\right)$ (Mehlich-1); Ca and $\mathrm{Mg}$ extracted by $\mathrm{KCl} 1 \mathrm{~mol} \mathrm{~L}^{-1}$ were determined; the potential acidity $(\mathrm{H}+\mathrm{Al})$ was extracted with $\mathrm{Ca}$ acetate $\left(\mathrm{Ca}\left(\mathrm{Ca}(\mathrm{OAc})_{2}-0.5 \mathrm{~mol} \mathrm{~L}^{-1}\right)\right.$ at $\mathrm{pH} 7$ and titrated with $\mathrm{NaOH} 0.005\left(\mathrm{~mol} \mathrm{~L}^{-1}\right)$. The available $\mathrm{P}$ was extracted by Mehlich-1 and, after ascorbic acid reduction, the $\mathrm{P}$ content determined by spectrophotometry (Embrapa, 1997).

From the above data, the sum of bases $\mathrm{SB}=(\mathrm{Ca}+$ $\mathrm{Mg}+\mathrm{K})$ and $\mathrm{CEC}$ at $\mathrm{pH} 7(\mathrm{~T})=\mathrm{SB}+(\mathrm{H}+\mathrm{Al})$ and base saturation $(\mathrm{V} \%)=\mathrm{SB} \times 100 / \mathrm{T}($ Embrapa, 1997) were calculated.

The contents of organic $\mathrm{C}$ and $\mathrm{N}$ were determined using a FlashEA® 1112 Elemental Analyzer, Series NCS (Nelson \& Sommers, 1996).

\section{Organic matter fractionation}

Organic matter of all samples of the profiles 1,2 and 3 was fractionated, by modified methods of the International Humic Substances Society (Swift, 1996).

\section{Microbial analysis}

Basal respiration was determined according to a methodology adapted from Alef \& Nannipieri (1995), as described by Campos (2009). In this procedure, the $\mathrm{KOH}$ solution concentration, incubated with the sample, was increased from 0.1 to $0.6 \mathrm{~mol} \mathrm{~L}^{-1}$. This adaptation was necessary because of the high respiration rate observed in the peat bog samples.

The $\mathrm{C}$ content in the microbial biomass was analyzed by the fumigation and extraction method proposed by Vance et al. (1987).

The metabolic quotient was calculated from the ratio between basal respiration and $\mathrm{C}$ content in the microbial biomass, and by multiplying the result by 100 .

The microbial quotient (qMIC) was calculated as the ratio between the $\mathrm{C}$ content in the microbial biomass and total soil $\mathrm{C}$ content and expressed as percentage.

\section{Isotopic composition and radiocarbon dating}

The two deepest layers of profile 1 and four layers of profile 4 were collected, air-dried, ground in a porcelain mortar and sieved ( $0.053 \mathrm{~mm}$ mesh), then sent to the laboratory of CENA/USP, for radiocarbon dating and isotopic composition $\left(\delta^{13} \mathrm{C}\right)$ by lowbackground liquid scintillation spectrometry (Pessenda \& Camargo, 1991).

From the difference between the radiocarbon ages, layer thickness and $\mathrm{C}$ content, the vertical growth rate $\left(\mathrm{mm}\right.$ year $\left.{ }^{-1}\right)$ and carbon accumulation rate $\left(\mathrm{g} \mathrm{m}^{-2}\right.$ year ${ }^{-1}$ ) of each peat profile was calculated (Campos, 2009).

\section{Statistical analysis}

For the statistical analysis a Cross Classification Design was used, where profiles and depths were the sources of variation. Means of profiles and depths were compared by the Tukey test $(p<0.05)$.

\section{RESULTS AND DISCUSSION}

\section{Morphological and physical characterization of soil profiles}

The color analysis showed higher intensity and chroma in the uppermost soil layers, with a tendency 
to decrease with depth (Table 2), evidencing a darker color of the peat in deeper than in surface layers, indicating a more advanced stage of organic matter decomposition (Embrapa, 2006).

The distribution of the organic matter decomposition stages in the three soil samples, as proposed by von Post, was the same (Embrapa, 2006). The two surface layers were classified as fibric, the two beneath as hemic and the four deepest as sapric peat (Table 2).

None of the properties presented in table 2 varied significantly among the profiles. However, among the different layers, the RF content was higher in surface layers (fibric), decreasing with increasing depth. The contents of MM and Ds tended to increase with depth, due to greater contact with the inorganic basal substrate and to the more advanced decomposition stage in the deeper layers, which were more consolidated than the uppermost layers (Gorham \& Janssens, 1992) corroborated by the increase in OMd with depth (Table 2).

\section{Chemical characterization}

Of the chemical properties presented in table 3, only $\mathrm{Ca}$, SB and V\% differed significantly in the profiles. The values of $\mathrm{Ca}$ and $\mathrm{SB}$, at a distance of about $60 \mathrm{~m}$ from the river bed of Córrego das Pedras, were therefore highest in profile 2 (P2). Although some properties differed in the profiles, the same was not observed at different depths (Table 3).

Active acidity $(\mathrm{pH})$ in the profiles was high, both in water and $\mathrm{CaCl}_{2}$, which is mainly caused by a high organic acid content in peat bogs (Silva et al., 2008).

The T content, was high in the three profiles mainly due to higher $\mathrm{C}$ values. According to Silva \& Mendonça

Table 2. Morphological and physical properties and decomposition stage of organic matter (von Post) of three peat profiles in EPA Pau-de-Fruta

\begin{tabular}{|c|c|c|c|c|c|c|c|}
\hline Profile & Depth & Color ${ }^{(1)}$ & von Post ${ }^{(2)}$ & $\mathrm{RF}^{(3)}$ & $\mathbf{M M}^{(4)}$ & $\mathbf{S d}^{(5)}$ & $\mathrm{OMd}^{(6)}$ \\
\hline \multirow{9}{*}{1} & $\mathrm{~cm}$ & Munsell & & \multicolumn{2}{|c|}{ _ dag kg-1 } & \multicolumn{2}{|c|}{$\longrightarrow \mathrm{g} \mathrm{cm}^{-3}$} \\
\hline & $0-27$ & $10 \mathrm{YR} 4 / 4$ & fíbrico & 60 & 28.0 & 0.10 & 0.07 \\
\hline & $27-54$ & 10 YR 4/4 & fíbrico & 65 & 28.1 & 0.13 & 0.09 \\
\hline & $54-81$ & 10 YR $3 / 4$ & hêmico & 42 & 30.0 & 0.16 & 0.11 \\
\hline & 81-108 & $10 \mathrm{YR} 3 / 3$ & hêmico & 48 & 8.7 & 0.09 & 0.08 \\
\hline & $108-135$ & 10 YR 3/2 & sáprico & 33 & 20.8 & 0.10 & 0.08 \\
\hline & $135-162$ & 10 YR $3 / 4$ & sáprico & 33 & 21.4 & 0.11 & 0.09 \\
\hline & $162-189$ & 10 YR $3 / 1$ & sáprico & 20 & 55.0 & 0.16 & 0.07 \\
\hline & $189-216$ & $10 \mathrm{YR} 3 / 3$ & sáprico & 17 & 56.9 & 0.26 & 0.11 \\
\hline \multicolumn{2}{|c|}{ Average Profile 1} & & & $39.7 \mathrm{~A}$ & $31.13 \mathrm{~A}$ & $0.14 \mathrm{~A}$ & $0.09 \mathrm{~A}$ \\
\hline \multirow{8}{*}{2} & $0-27$ & 10 YR 4/5 & fíbrico & 55 & 26.8 & 0.12 & 0.08 \\
\hline & $27-54$ & 10 YR $4 / 4$ & fíbrico & 53 & 29.3 & 0.13 & 0.08 \\
\hline & $54-81$ & 10 YR $4 / 4$ & hêmico & 46 & 27.3 & 0.12 & 0.08 \\
\hline & 81-108 & $10 \mathrm{YR} 4 / 4$ & hêmico & 44 & 27.7 & 0.12 & 0.09 \\
\hline & $108-135$ & 10 YR 4/2 & sáprico & 35 & 33.8 & 0.13 & 0.11 \\
\hline & $135-162$ & 10 YR $4 / 2$ & sáprico & 33 & 35.9 & 0.15 & 0.09 \\
\hline & $162-189$ & 10 YR 3/1 & sáprico & 22 & 44.9 & 0.15 & 0.10 \\
\hline & $189-216$ & $10 \mathrm{YR} 3 / 2$ & sáprico & 20 & 47.0 & 0.18 & 0.12 \\
\hline \multicolumn{2}{|c|}{ Average Profile 2} & & & $38.5 \mathrm{~A}$ & $34.09 \mathrm{~A}$ & $0.14 \mathrm{~A}$ & $0.18 \mathrm{~A}$ \\
\hline \multirow{8}{*}{3} & $0-27$ & $10 \mathrm{YR} 4 / 4$ & fíbrico & 67 & 31.1 & 0.08 & 0.08 \\
\hline & $27-54$ & 10 YR $4 / 4$ & fíbrico & 58 & 28.3 & 0.11 & 0.07 \\
\hline & $54-81$ & $10 \mathrm{YR} 4 / 3$ & hêmico & 55 & 20.4 & 0.1 & 0.07 \\
\hline & 81-108 & 10 YR 4/2 & hêmico & 43 & 35.8 & 0.09 & 0.09 \\
\hline & $108-135$ & 10 YR $3 / 2$ & sáprico & 48 & 37.9 & 0.16 & 0.12 \\
\hline & $135-162$ & 10 YR $3 / 1$ & sáprico & 37 & 42.0 & 0.17 & 0.12 \\
\hline & $162-189$ & 10 YR 3/1 & sáprico & 16 & 49.6 & 0.28 & 0.13 \\
\hline & $189-216$ & 10 YR 3/2 & sáprico & 21 & 47.7 & 0.26 & 0.13 \\
\hline \multicolumn{2}{|c|}{ Average Profile 3} & & & $43.1 \mathrm{~A}$ & $36.60 \mathrm{~A}$ & $0.14 \mathrm{~A}$ & $0.10 \mathrm{~A}$ \\
\hline \multirow{8}{*}{$\begin{array}{l}\text { Averages of } \\
\text { layers }\end{array}$} & $0-27$ & - & fíbrico & $60.7 \mathrm{a}$ & $28.6 \mathrm{bc}$ & $0.10 \mathrm{~b}$ & $0.07 \mathrm{a}$ \\
\hline & $27-54$ & - & fíbrico & $58.7 \mathrm{ab}$ & $28.6 \mathrm{bc}$ & $0.12 \mathrm{~b}$ & $0.08 \mathrm{a}$ \\
\hline & $54-81$ & - & hêmico & $47.7 \mathrm{bc}$ & $25.9 \mathrm{c}$ & $0.13 \mathrm{~b}$ & $0.09 \mathrm{a}$ \\
\hline & $81-108$ & - & hêmico & $45.0 \mathrm{bcd}$ & $24.1 \mathrm{c}$ & $0.10 \mathrm{~b}$ & $0.09 \mathrm{a}$ \\
\hline & $108-135$ & - & sáprico & $38.7 \mathrm{~cd}$ & $30.8 \mathrm{a} b c$ & $0.13 \mathrm{ab}$ & $0.10 \mathrm{a}$ \\
\hline & $135-162$ & - & sáprico & $34.3 \mathrm{~cd}$ & $33.1 \mathrm{abc}$ & $0.14 \mathrm{ab}$ & $0.10 \mathrm{a}$ \\
\hline & $162-189$ & - & sáprico & $19.3 \mathrm{e}$ & $49.8 \mathrm{ab}$ & $0.16 \mathrm{ab}$ & $0.10 \mathrm{a}$ \\
\hline & $189-216$ & - & sáprico & $19.3 \mathrm{e}$ & $50.5 \mathrm{a}$ & $0.23 \mathrm{a}$ & $0.12 \mathrm{a}$ \\
\hline
\end{tabular}

(1) Color: color evaluated in sodium pyrophosphate. ${ }^{(2)}$ von Post: Scale of Organic Matter Decomposition. ${ }^{(3)}$ RF: rubbed fiber. (4) MM: mineral material. ${ }^{(5)} \mathrm{Sd}$ : soil density. ${ }^{(6)} \mathrm{OMd}$ : organic matter density. Averages of the profiles followed by the same capital letters in columns and means of the layers followed by the same lowercase letters in columns do not differ significantly by the Tukey test $(\mathrm{p}<0.05)$. 
Table 3. Chemical properties of three peat profiles in EPA Pau-de-Fruta

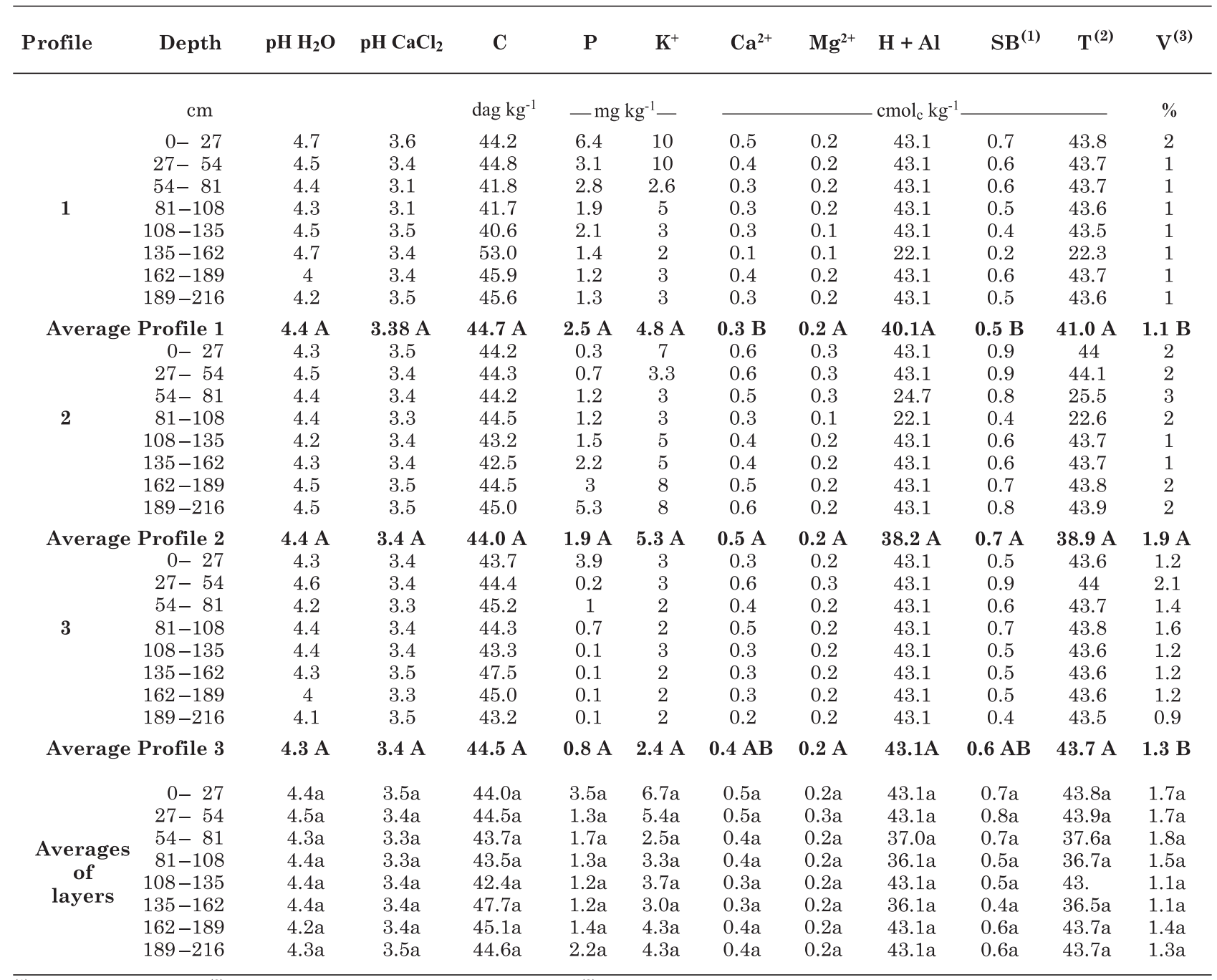

(1) SB: sum of bases. ${ }^{(2)} \mathrm{T}$ : cation exchange capacity at $\mathrm{pH} 7{ }^{\left({ }^{(3)} \mathrm{V} \text { : base saturation. Averages of the profiles followed by the same }\right.}$ capital letters in columns and means of the layers followed by the same lowercase letters in columns do not differ significantly by the Tukey test $(\mathrm{p}<0.05)$.

(2007) almost all T values in Organosols are related to elevated $\mathrm{C}$ contents.

\section{Characterization of organic matter}

The contents of $\mathrm{H}, \mathrm{HA}$ and $\mathrm{C}$ did not differ statistically between the profiles (Table 4). However, the $\mathrm{FA}$ content and ratios of $\mathrm{EA} / \mathrm{H}$ and $\mathrm{C} / \mathrm{N}$ were highest in profile 3 (P3), while the HA/FA ratio was highest in $\mathrm{P} 2$ and the average $\mathrm{N}$ content highest in profile P1 (Table 4). These values can be related to the landscape position of the profiles. P1 is located in a flat area, at a distance of about $100 \mathrm{~m}$ from the bed of Córrego das Pedras, P2 is also in a flat topography, but $60 \mathrm{~m}$ away from the bed of Córrego das Pedras and P3 is only $3 \mathrm{~m}$ away from the river bed, in a little active topography, in which the lateral water flow is probably more intense than in $\mathrm{P} 1$ and $\mathrm{P} 2$ (Figure 1).
When analyzed at different depths, $\mathrm{H}$ values were highest in the surface layers (Table 4), where the stage of organic matter decomposition is less advanced (fibric) and in deeper layers, possibly due to formation of organo-mineral complexes, which stabilize organic matter decomposition, thus increasing the soil $\mathrm{H}$ content (Breemen \& Buurman, 2002). According to Silva \& Mendonça (2007), aside from physical protection, the soil silt and clay fractions provide chemical and colloidal protection. However, according to these authors, studies on the interaction between humic substances with the mineral fraction in the soil are still preliminary.

The $\mathrm{N}$ content also decreased with depth, as related to the advancing decomposition of organic matter (Table 4).

The HA contents and HA/FA and $\mathrm{EA} / \mathrm{H}$ ratios were highest in the intermediate layers of the three profiles 
Table 4. Humic substances, $\mathrm{C}$ and $\mathrm{N}$ contents and $\mathrm{C} / \mathrm{N}$ ratio of organic matter in three peat profiles of EPA Pau-de-Fruta

\begin{tabular}{|c|c|c|c|c|c|c|c|c|c|}
\hline \multirow{2}{*}{ Profile } & \multirow{2}{*}{ Depth } & \multicolumn{3}{|c|}{$\mathbf{C}$} & \multirow{2}{*}{ HA/FA } & \multirow{2}{*}{$\mathrm{EA} / \mathrm{H}^{(4)}$} & \multirow{2}{*}{$\mathrm{N}^{(5)}$} & \multirow{2}{*}{$C^{(6)}$} & \multirow{2}{*}{$\mathrm{C} / \mathrm{N}^{(7)}$} \\
\hline & & $\mathbf{H}^{(1)}$ & $\mathrm{HA}^{(2)}$ & $\mathrm{FA}^{(3)}$ & & & & & \\
\hline \multirow{9}{*}{1} & $\mathrm{~cm}$ & & $-\%$ & - & & & \multicolumn{2}{|c|}{ dag kg $^{-1}{ }_{-}$} & \\
\hline & $0-27$ & 66.96 & 24.61 & 8.43 & 2.92 & 0.49 & 2.10 & 44.2 & 14.96 \\
\hline & $27-54$ & 67.80 & 25.08 & 7.13 & 3.52 & 0.48 & 1.63 & 44.8 & 20.26 \\
\hline & $54-81$ & 48.20 & 43.57 & 8.23 & 5.29 & 1.07 & 1.36 & 41.8 & 23.26 \\
\hline & $81-108$ & 46.84 & 44.37 & 8.79 & 5.05 & 1.13 & 0.94 & 41.7 & 29.33 \\
\hline & $108-135$ & 46.90 & 42.77 & 10.33 & 4.14 & 1.13 & 0.77 & 40.6 & 38.58 \\
\hline & $135-162$ & 50.84 & 38.55 & 10.61 & 3.63 & 0.97 & 0.70 & 53.0 & 39.26 \\
\hline & $162-189$ & 54.09 & 35.61 & 10.3 & 3.46 & 0.85 & 0.72 & 45.9 & 37.14 \\
\hline & $189-216$ & 58.26 & 31.50 & 10.24 & 3.08 & 0.72 & 0.73 & 45.6 & 44.73 \\
\hline \multicolumn{2}{|c|}{ Average Profile 1} & $54.99 \mathrm{~A}$ & $35.76 \mathrm{~A}$ & $9.26 \mathrm{~A}$ & $3.89 \mathrm{~B}$ & $0.86 \mathrm{~B}$ & $1.12 \mathrm{~A}$ & $44.7 \mathrm{~A}$ & $30.90 \mathrm{~B}$ \\
\hline \multirow{8}{*}{2} & $0-27$ & 63.14 & 30.46 & 6.4 & 4.76 & 0.58 & 1.91 & 44.2 & 16.87 \\
\hline & $27-54$ & 63.65 & 30.07 & 6.27 & 4.80 & 0.57 & 1.77 & 44.3 & 17.11 \\
\hline & $54-81$ & 61.49 & 31.94 & 6.57 & 4.86 & 0.63 & 1.14 & 44.2 & 26.06 \\
\hline & 81-108 & 50.88 & 42.61 & 6.51 & 6.55 & 0.97 & 0.91 & 44.5 & 29.59 \\
\hline & $108-135$ & 48.59 & 44.78 & 6.63 & 6.75 & 1.06 & 0.72 & 43.2 & 39.92 \\
\hline & $135-162$ & 58.00 & 35.05 & 6.95 & 5.05 & 0.72 & 0.73 & 42.5 & 39.96 \\
\hline & $162-189$ & 58.42 & 33.43 & 8.15 & 4.10 & 0.71 & 0.87 & 44.5 & 35.76 \\
\hline & $189-216$ & 57.22 & 32.44 & 10.34 & 3.14 & 0.75 & 0.67 & 45.0 & 40.55 \\
\hline \multicolumn{2}{|c|}{ Average Profile 2} & $57.67 \mathrm{~A}$ & $35.1 \mathrm{~A}$ & $7.23 \mathrm{~B}$ & $5.00 \mathrm{~A}$ & $0.75 \mathrm{~A}$ & $1.09 \mathrm{AB}$ & $44.0 \mathrm{~A}$ & $30.73 \mathrm{~B}$ \\
\hline \multirow{8}{*}{3} & $0-27$ & 64.29 & 26.22 & 9.49 & 2.76 & 0.56 & 1.83 & 43.7 & 18.32 \\
\hline & $27-54$ & 58.51 & 33.83 & 7.66 & 4.42 & 0.71 & 0.87 & 44.4 & 27.77 \\
\hline & $54-81$ & 52.26 & 38.89 & 8.85 & 4.39 & 0.91 & 1.01 & 45.2 & 26.25 \\
\hline & $81-108$ & 46.72 & 43.82 & 9.47 & 4.63 & 1.14 & 0.76 & 44.3 & 38.54 \\
\hline & $108-135$ & 40.08 & 50.86 & 9.06 & 5.62 & 1.49 & 0.69 & 43.3 & 42.42 \\
\hline & $135-162$ & 60.04 & 29.82 & 10.14 & 2.94 & 0.67 & 0.79 & 47.5 & 37.04 \\
\hline & $162-189$ & 57.13 & 30.46 & 12.42 & 2.45 & 0.75 & 0.62 & 45.0 & 41.47 \\
\hline & $189-216$ & 55.77 & 30.95 & 13.27 & 2.33 & 0.79 & 0.45 & 43.2 & 56.16 \\
\hline \multirow[t]{2}{*}{ Average } & Profile 3 & $54.35 \mathrm{~A}$ & $35.61 \mathrm{~A}$ & $10.04 \mathrm{~A}$ & $3.69 \mathrm{~B}$ & $0.88 \mathrm{~A}$ & $0.88 \mathrm{~B}$ & $44.5 \mathrm{~A}$ & $36.00 \mathrm{~A}$ \\
\hline & $0-27$ & $64.80 \mathrm{a}$ & $27.10 \mathrm{~b}$ & $8.11 \mathrm{~b}$ & $3.48 \mathrm{ab}$ & $0.54 \mathrm{~b}$ & $1.95 \mathrm{a}$ & $44.0 \mathrm{a}$ & $16.72 \mathrm{~b}$ \\
\hline \multirow{7}{*}{$\begin{array}{c}\text { Averages } \\
\text { of } \\
\text { layers }\end{array}$} & $27-54$ & $63.32 \mathrm{a}$ & $29.66 \mathrm{~b}$ & $7.02 \mathrm{~b}$ & $4.25 \mathrm{ab}$ & $0.59 \mathrm{~b}$ & $1.42 \mathrm{ac}$ & $44.5 \mathrm{a}$ & $21.71 \mathrm{bc}$ \\
\hline & $54-81$ & $53.98 \mathrm{ab}$ & $38.13 \mathrm{ab}$ & $7.88 \mathrm{bc}$ & $4.85 \mathrm{ab}$ & $0.87 \mathrm{ab}$ & $1.17 \mathrm{bc}$ & $43.7 \mathrm{a}$ & $25.19 \mathrm{bc}$ \\
\hline & $81-108$ & $48.15 \mathrm{~b}$ & $43.60 \mathrm{a}$ & $8.26 \mathrm{bc}$ & $5.41 \mathrm{a}$ & $1.08 \mathrm{a}$ & $0.87 \mathrm{bc}$ & $43.5 \mathrm{a}$ & $32.49 \mathrm{~cd}$ \\
\hline & $108-135$ & $45.19 \mathrm{~b}$ & $46.14 \mathrm{a}$ & $8.67 \mathrm{abc}$ & $5.50 \mathrm{a}$ & $1.23 \mathrm{a}$ & $0.73 \mathrm{~b}$ & $42.4 \mathrm{a}$ & $40.31 \mathrm{ad}$ \\
\hline & $135-162$ & $56.29 \mathrm{a}$ & $34.47 \mathrm{~b}$ & $9.23 \mathrm{abc}$ & $3.87 \mathrm{ab}$ & $0.79 \mathrm{ab}$ & $0.74 \mathrm{~b}$ & $47.7 \mathrm{a}$ & $38.75 \mathrm{ad}$ \\
\hline & $162-189$ & $56.55 \mathrm{a}$ & $33.17 \mathrm{~b}$ & $10.29 \mathrm{ac}$ & $3.34 \mathrm{ab}$ & $0.77 \mathrm{ab}$ & $0.74 \mathrm{~b}$ & $45.1 \mathrm{a}$ & $38.12 \mathrm{ad}$ \\
\hline & $189-216$ & $57.08 \mathrm{a}$ & $31.63 \mathrm{~b}$ & $11.28 \mathrm{a}$ & $2.85 \mathrm{~b}$ & $0.75 \mathrm{~b}$ & $0.62 \mathrm{~b}$ & $44.6 \mathrm{a}$ & $47.15 \mathrm{a}$ \\
\hline
\end{tabular}

${ }^{(1)} \mathrm{H}$ : Humin. ${ }^{\left({ }^{2}\right)}$ HA: Humic Acid. ${ }^{(3)}$ AF: Fulvic Acid. ${ }^{(4)}$ EA (Humic Acid + Fulvic Acid). ${ }^{(5)}$ N: Nitrogen. ${ }^{(6)}$ C: Carbon. ${ }^{(7)}$ C/N: Carbon/ Nitrogen ratio. Averages of the profiles followed by the same capital letters in columns and means of the layers followed by the same lowercase letters in columns do not differ significantly by the Tukey test $(p<0.05)$.

studied (Table 4). Higher HA/FA ratios indicate a higher degree of polymerization of soluble organic matter in relation to other parts of the profile (Cunha et al., 2005). Also according to the above author, the $\mathrm{AH} / \mathrm{AF}$ ratio of hydromorphic soils in the tropics tends to be $>1$, due to the higher mobility and lower condensation of the FA than of the HA fraction. Carbon mobility in these layers is higher than in others, as indicated by $\mathrm{AF}$ and a higher $\mathrm{EA} / \mathrm{H}$ ratio, where EA is the sum of soluble fractions of humidified organic matter $(\mathrm{HA}+\mathrm{FA})$ and $\mathrm{H}$ the insoluble fraction (Benites et al., 2000).

\section{Microbial characterization}

There were no significant changes in basal respiration, in $\mathrm{C}$ content of the microbial biomass,
$\mathrm{qCO}_{2}$ and in qMIC among the profiles studied (Table 5) and comparing depths, it was observed that $\mathrm{qCO}_{2}$ did not change significantly (Table 5), indicating that the $\mathrm{C}$ assimilation efficiency of the microbial biomass did not change significantly in the profile. According to Anderson \& Domsch (1985), the more efficiently the microbial biomass can use resources of the environment, the less $\mathrm{C}$ is lost in $\mathrm{CO}_{2}$ through respiration, which can be incorporated into microbial tissue, resulting in a low $\mathrm{q} \mathrm{CO}_{2}$.

The highest basal respiration rate (Cmic) was observed in the upper layers, where the $\mathrm{N}$ contents were greatest and $\mathrm{C} / \mathrm{N}$ ratio lowest (Table 5) and where organic matter was in a less advanced decomposition stage (Table 2). Similar behavior was observed for qMIC, differing only in the deepest (sapric) layer which 
Table 5. Basal respiration, microbial biomass carbon, metabolic quotient $\left(\mathrm{qCO}_{2}\right)$ and microbial quotient (qMIC) of three peat profiles of EPA Pau-de-Fruta

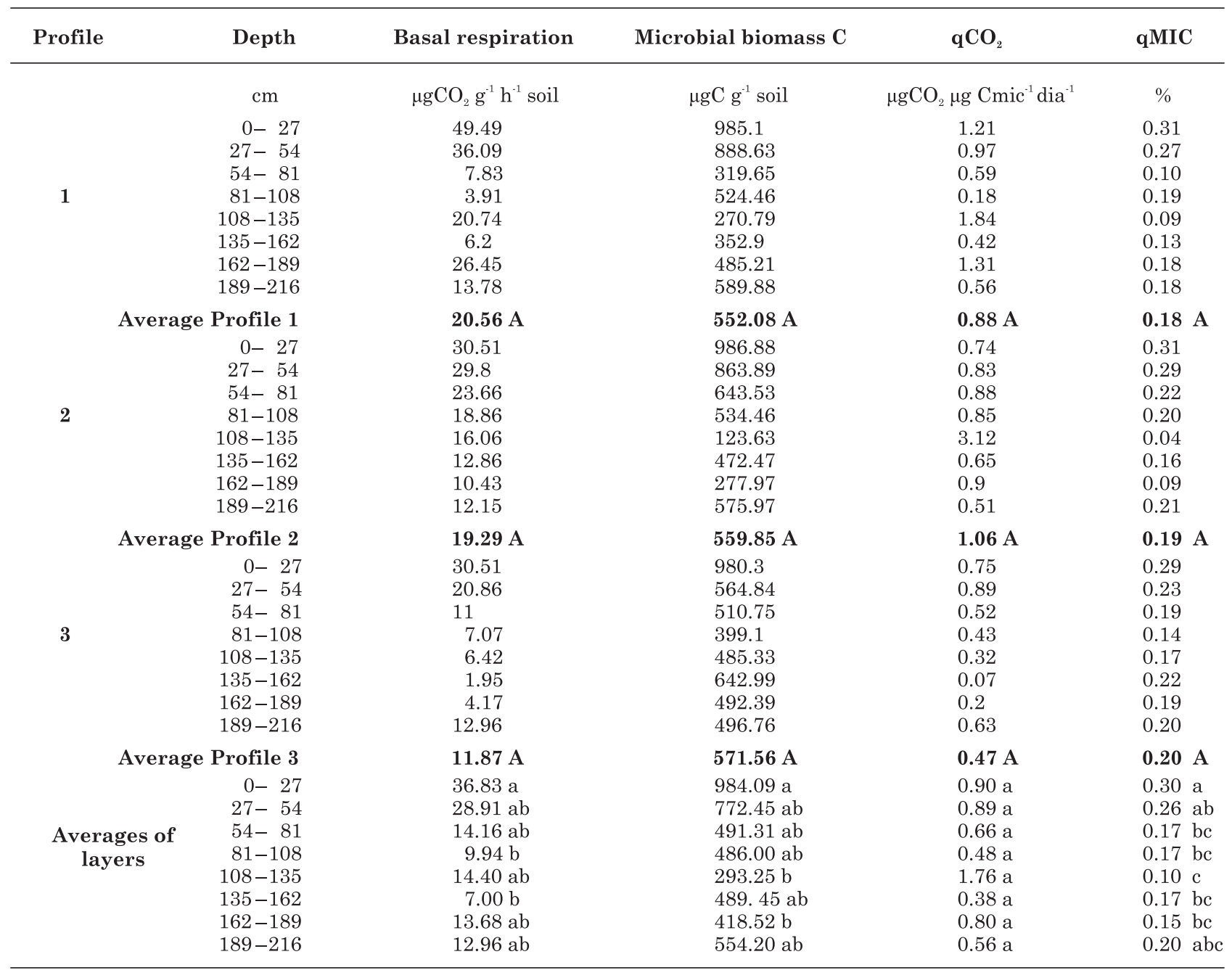

Averages of the profiles followed by the same capital letters in columns and means of the layers followed by the same lowercase letters in columns do not differ significantly by the Tukey test $(p<0.05)$.

was statistically not different from the surface layers. According to Pontevedra-Pombal, 2002, in a peat environment, more stable temperature, combined with the recalcitrant material and low $\mathrm{O}_{2}$ and nutrient availability are mainly responsible for the reduction in microbial activity in subsurface layers. Under these conditions, the ability to use soil carbon by microorganisms is reduced, resulting in reduced qMIC values (Mendes et al., 2009).

\section{Peat bog development, carbon accumulation rate and vegetation cover chronology}

The peat bogs of SdEM overlay predominantly quartzite rocks with occurrence of hematite phyllites, in depressed areas of the landscape (Abreu, 1982). In this environment, due to the chemical nature and high resistance of quartzite rocks to weathering, sandy, shallow and very nutrient-poor soils are formed, on which vegetation adapted to the hydromorphism conditions is developed which accumulates plant material with every cycle, forming peat (Silva, 2005).

In the peat bog of EPA Pau-de-Fruta, the annual growth rate observed in $\mathrm{P} 1$, in the layer 175.5 $202.5 \mathrm{~cm}$, was $0.143 \mathrm{~mm}_{\text {year }}{ }^{-1}$. In $\mathrm{P} 4$, in the upper layer $(23.3-42.3 \mathrm{~cm})$, the vertical growth rate was $0.074 \mathrm{~mm}$ year $^{-1} ; 0.113 \mathrm{~mm}_{\text {year }}{ }^{-1}$ in the layer $42.3-$ 70.8 ; and $0.069 \mathrm{~mm}^{-1} \mathrm{year}^{-1}$ in $70.8-175.3 \mathrm{~cm}$ favor verificar a correção (Table 6). These values are lower than of peat bogs in Finland, Canada and Spain (Tolonen, 1979; Gorham, 1991; Pontevedra-Pombal, 2002), respectively.

The annual $\mathrm{C}$ accumulation rate in $\mathrm{P} 1$, in the layer 175.5-202.5 $\mathrm{cm}$ was $16.9 \mathrm{~g} \mathrm{~m}^{-2}$ year $^{-1}$ (Table 6). In $\mathrm{P} 4$, an annual accumulation of $10.4 \mathrm{~g} \mathrm{~m}^{-2}$ year-1 $^{-1}$ was observed in the layer $23.3-42.3 \mathrm{~cm}$, while in the layer $42.3-70.8 \mathrm{~cm}$, this rate was $20.4 \mathrm{~g} \mathrm{~m}^{-2}$ year $^{-1}$. In the deepest profile layer $(70.8-175.3 \mathrm{~cm})$, the 
Table 6. Radiocarbon age. isotopic composition. vertical growth rate and carbon accumulation in layers of two peat profiles of EPA Pau-de-Fruta

\begin{tabular}{|c|c|c|c|c|c|c|}
\hline Profile & Depth & Average depth & Age ${ }^{14} \mathrm{C}$ & $\delta^{13} C^{(1)}$ & Vertical growth & $\mathrm{RCA}^{(2)}$ \\
\hline & $\mathrm{cm}$ & $\mathrm{cm}$ & years AP & $\%$ & $\mathrm{~mm}$ ano ${ }^{-1}$ & $\mathrm{~g} \mathrm{~m}^{-2}$ ano $^{-1}$ \\
\hline 1 & $\begin{array}{l}162-189 \\
189-216\end{array}$ & $\begin{array}{l}175.5 \\
202.5\end{array}$ & $\begin{array}{l}7.510 \pm 80 \\
9.400 \pm 90\end{array}$ & $\begin{array}{l}-21.2 \\
-19.6\end{array}$ & 0.143 & 16.9 \\
\hline 4 & $\begin{array}{c}18.5-28 \\
37.5-47 \\
66-75.5 \\
170.5-180\end{array}$ & $\begin{array}{r}23.25 \\
42.25 \\
70.75 \\
175.25\end{array}$ & $\begin{aligned} 190 & \pm 70 \\
2.750 & \pm 70 \\
5.270 & \pm 80 \\
20.359 & \pm 230\end{aligned}$ & $\begin{array}{l}-20.5 \\
-20.2 \\
-20.8 \\
-20.9\end{array}$ & $\begin{array}{l}0.074 \\
0.113 \\
0.069\end{array}$ & $\begin{array}{l}10.4 \\
20.4 \\
13.7\end{array}$ \\
\hline
\end{tabular}

${ }^{(2)} \delta^{13} \mathrm{C}$ : isotopic composition. ${ }^{(2)} \mathrm{CAR}$ : carbon accumulation rate.

accumulation rate was $13.7 \mathrm{~g} \mathrm{~m}^{-2}$ year-1 $^{-1}$ (Table 6). These values are lower than those found in peat bogs of Russia, Spain and Canada (Tolonen, 1979; Armentano \& Menges, 1986; Gorham, 1991), respectively.

From the radiocarbon ages (Table 6), the position and altitude of $\mathrm{P} 1$ and $\mathrm{P} 4$ profiles (Figure 1, Table 1), as well as from data of Horak (2010), it was inferred that the peat bog development began in the highest part of the watershed of Córrego das Pedras and extended gradually to the lower parts.

The $\delta^{13} \mathrm{C}$ contents found in the two deepest P1 layers (Table 6) allow no conclusions on whether species of the photosynthetic pathways CAM, $\mathrm{C}_{3}$ or $\mathrm{C}_{4}$ were predominant in the area at the beginning of peat formation. However, the data indicated that between 9,400 and 7,510 years BP the native vegetation consisted of species with photosynthetic cycles $\mathrm{CAM}$ and $\mathrm{C}_{4}$, with influence of $\mathrm{C}_{3}$ species (shrubs), as observed today.

The $\delta^{13} \mathrm{C}$ contents obtained in $\mathrm{P} 4$ (Table 6) corroborate the inferences based on the analysis of $\delta^{13} \mathrm{C}$ contents of $\mathrm{P} 1$. From 20,359 years to 190 years $\mathrm{BP}$, the native vegetation of this peat profile was probably formed by species of the photosynthetic cycles $\mathrm{CAM}$ and $\mathrm{C}_{4}$, with influence of $\mathrm{C}_{3}$ species (shrubs), a vegetation that is typical in montane grasslands (Ribeiro \& Walter, 1998) and remains until today.

\section{CONCLUSIONS}

1. The structural organization of the profiles was homogeneous. The stage of organic matter decomposition of the peat bog studied increases with depth.

2. In the topmost layers of the peat bog, $\mathrm{N}$ contents and rates of basal respiration and Cmic were highest. The qMIC was lowest in the intermediate layer of the profiles.

3. The peat formation in EPA Pau-de-Fruta began about 20,000 years BP and the vegetation has not varied significantly since then.

\section{LITERATURE CITED}

ABREU, A.A. Análise geomorfológica: Reflexão e aplicação; Uma contribuição ao conhecimento das formas de relevo do Planalto de Diamantina-MG. São Paulo, Universidade de São Paulo, 1982. 296p. (Tese de Livre Docência)

ANDERSON, T.H. \& DOMSCH, K.H. Determination of ecophysiological maintenance carbon requirements of soil microorganisms in a dormant state. Biol. Fert. Soils, 1:8189, 1985.

ALEF, K. \& NANNIPIER, P. Methods in applied soil microbiology and biochemistry. London, Academic, 1995. 576p.

ALMEIDA ABREU, P.A. Geologia das quadrículas Onça e Cuiabá (Gouveia-MG) - Região Mediana Central da Serra do Espinhaço Meridional, 1989. Belo Horizonte, Universidade Federal de Minas de Gerais, 1989. (Tese de Mestrado)

ARMENTANO, T.V. \& MENGES, E.S. Patterns of change in the carbon balance of organic soil-wetlands of the temperature zone. J. Ecol., 74:755-774, 1986. Disponível em: <http://www.jstor.org> Acesso em: 22 de nov., 2008.

AUGUSTIN, C.H.R.R. Amphitheaters and hollows with depositional sequences and their significance on the evolution of tropical landscape. In: INTERNATIONAL SEDIMENTOLOGY CONGRESS, 14., Recife, 1994. Anais... Recife, IAS/UFPE. 1994. p.G5.

BENITES, V.M.; KER, J.C. \& MENDONCA, E.S. Fracionamento quantitativo de substâncias húmicas como auxiliar na identificação de diferentes solos da região Sul do Brasil. In: REUNIÃO DE CLASSIFICAÇÃO, CORRELAÇÃO E APLICAÇÃO DE LEVANTAMENTOS DE SOLOS, 2000, Colombo. Anais... 6. Guia de excursão de estudos de solos nos estados do Rio Grande do Sul, Santa Catarina e Paraná. Colombo, Embrapa Florestas, 2000. p.184-192.

BOUTTON, T.W. Stable carbon isotopes ratios of natural materials. II. Atmospheric, terrestrial, marine and freshwater environmental. In: COLEMAN, D.C. \& FRY, B., eds. Carbon isotopes techniques. New York, Academic Press, 1991. p.155-171.

BREEMEN, N.V. \& BUURMAN, P. Soil formation. Dordrecht, Kluwer, 2002. 376p. 
CAMPOS, J.R.R. Caracterização, mapeamento, volume de água e estoque de carbono da turfeira da área de proteção ambiental Pau-de-Fruta, Diamantina - MG. Diamantina, Universidade Federal dos Vales do Jequitinhonha e Mucuri, 2009. 101p. (Tese de Mestrado)

CUNHA, T.J.F.; CANELLAS, L.P.; SANTOS, G.A. \& RIBEIRO, L.P. Fracionamento da matéria orgânica humificada em solos brasileiros. In: CANELLAS, L.P. \& SANTOS, G.A. Humosfera, Tratado preliminar sobre a química das substâncias húmicas. Campos dos Goytacazes, Universidade Estadual do Norte Fluminense, 2005. p.5480. Disponível em: <http://www.uenf.br/> Acesso em: 10 de dez. 2008.

EMPRESA BRASILEIRA DE PESQUISA AGROPECUARIA EMBRAPA. Manual de métodos de análise de solos. 2.ed. Rio de Janeiro, Centro Nacional de Pesquisa de Solos, 1997. $212 \mathrm{p}$

EMPRESA BRASILEIRA DE PESQUISA AGROPECUÁRIA . EMBRAPA. Centro Nacional de Pesquisa de Solos. Sistema brasileiro de classificação de solos. Brasília, Embrapa Produção de Informação; Rio de Janeiro, Embrapa Solos, 2006

GORHAM, E. Northern peatlands: Role in the carbon cycle and probable responses to climatic warming. Ecol. Applications, 1:182-195, 1991. Disponível em: <http:// www.jstor.org/pss/1941811> Acesso em: 22 de nov. 2008.

GORHAM, E. \& JANSSENS, J.A. The paleorecord of geochemistry and hydrology in northern peatlands and its relation to global change. Suo, 43:9-19, 1992.

GOUVEIA, S.E.M.; PESSENDA, L.C.R.; ARAVENA, R.; BOULET, R.; ROVERATTI, R. \& GOMES, B.M. Dinâmica de vegetações durante o Quaternário Rmecente no $\mathrm{Sul}$ do Amazonas indicadas pelos isótopos de carbono $\left({ }^{12} \mathrm{C}\right.$, $\left.{ }^{13} \mathrm{C},{ }^{14} \mathrm{C}\right)$ do solo. Geochim. Bras., 11:355-367, 1997.

HORAK, I. Relações pedológicas, isotópicas e palinológicas na reconstrução paleoambiental da turfeira da Área de Proteção Especial (APE) Pau-de-Fruta, Serra do Espinhaço Meridional - MG. Piracicaba, Escola Superior de Agricultura Luiz de Queiroz/USP, 2010. 281p. (Tese de Mestrado)

JEDRYSEK, M.O.; KRAPIEC, M.; SKRZYPEK, G. \& KALUZNY, A. Air-pollution effect and paleotemperature scale versus $\delta^{13} \mathrm{C}$ records and tree rings and peat core (Southern Poland). Water Air Soil Poll., 145:359-375, 2003.

MARTINELLI, L.A.; OMETTO, J.P.H.B.; FERRAZ, E.S.; VICTORIA, R.L.; CAMARGO, P.B.C. \& MOREIRA, Z. Desvendando questões ambientais com isótopos estáveis. São Paulo, Oficina de Textos, 2009. 130p.

MARTINEZ-CORTIZAS, A.; PONTEVEDRA-POMBAL, X.; NOVOA-MUNHOZ, J.C. \& GARCIA- RODEJA, E. Four thousand years of atmospheric $\mathrm{Pb}, \mathrm{Cd}$ and $\mathrm{Zn}$ deposition recorded by the ombrotrophic peat bog of Penido Vello (Northwestern Espain) Wather Air Soil Poll., 100:387403, 1997.

MARTINEZ-CORTIZAS, A.; PONTEVEDRA-POMBAL, X.; GARCIA-RODEJA, E.; NOVOA MUNHOZ, J.C. \& SHOTYK, W. Mercury in a Spanish peat bog: Archive of climate change and atmospheric metal deposition. Science, 284:939-942, 1999
MENDES, I.C.; HUNGRIA, M.; REIS-JUNIOR, F.B.; FERNANDES, M.F.; CHAER, G.M.; MERCANTE, F.M. \& ZILLI, J.E. Bioindicadores para avaliação dos solos tropicais: Utopia ou realidade? In: CONGRESSO BRASILEIRO DE CIÊNCIA DO SOLO, 32., Fortaleza, 2009. Anais. Fortaleza, SCBS, 2009. CD-ROM.

NELSON, D.W. \& SOMMERS, L.E. Total carbon, organic carbon and organic matter. In: SPARKS, D.L. Methods of soil analysis. Chemical methods. Madison, Soil Science Society America/American Society Agronomy, 1996. Part 3. p.961-1009.

NEVES, S.C.; ABREU, P.A. \& FRAGA, L.M.S. Fisiografia. In: SILVA, A.C.; PEDREIRA, L.C.V.S.F. \& ABREU, O.A. Serra do Espinhaço Meridional: Paisagem e ambiente. Belo Horizonte, O Lutador, 2005. p.137-147.

PESSENDA, L.C.R. \& CAMARGO, P.B. Datações radiocarbônicas de amostras de interesse arqueológico e geológico por espectrometria de cintilação líquida de baixa radiação de fundo. Química Nova, 14:98-103, 1991.

PONTEVEDRA-POMBAL, X. Turberas de Montaña de Galícia: Génesis, propiedades y su aplicación como registros ambientales geoquímicos. Santiago de Compostela, Universidade de Santiago de Compostela, 2002. 489p. (Tese de Doutorado)

RIELEY, J.O.; WUST, R.A.J.; JAUHIAINEN, J.; PAGE, S.E.; WOSTEN, H.; HOOIJER, A.; SIEGERT, F.; LIMIM,S.H.; VASANDER, H. \& STAHLHUT, M. Tropical Peatlands: Carbon stores, carbon gas emissions and contribution to climate change processes. In: STRACK, M. Peatlands and climate change. Calgary, Peat Society, 2008. p.44-70.

RIBEIRO, J.F. \& WALTER, B.M.T. Fitofisionomias do bioma cerrado. In: SANO, S.M. \& ALMEIDA, S.P. Cerrado: Ambiente e flora. Planaltina, Embrapa-CPAC, 1998. p.89166.

SAADI, A.A Geomorfologia da Serra do Espinhaço em Minas Gerais e de suas margens. Geonomos, 3:41-75, 1995. Disponível em: <http://www.igc.ufmg.br/geonomos/ PDFs>. Acesso em: 26 nov. 2008.

SHOTYK, W.; WEISS, D.; APPLEBY, P.G.; CHEBURKIN, A.K.; FREI, R.; GLOOR, M.; KRAMERS, J.D.; REESE, S. \& van der KNAAP, W.O. History of atmospheric lead deposition since $12.730{ }^{14} \mathrm{C}$ yr BP from a peat bog, Jura Mountains, Switzerland. Science, 281:1635-1640, 1998.

SILVA, A.C. Diagnóstico e avaliação pedológica para o plano de manejo do Parque Estadual do Biribiri. Diamantina, SEMAD/IEF, 2004a. 37p.

SILVA, A.C. Diagnóstico e avaliação pedológica para o plano de manejo do Parque Estadual do Rio Preto. Diamantina, SEMAD/IEF, 2004b. 34p.

SILVA, A.C. Diagnóstico e avaliação pedológica para o plano de manejo do Parque Estadual do Pico do Itambé. Diamantina, SEMAD/IEF, 2004c. 31p.

SILVA, A.C. Diagnóstico e avaliação pedológica para o plano de manejo da Área de Proteção Ambiental Águas Vertentes. Diamantina, SEMAD/IEF, 2005. 53p.

SILVA, A.C.; PEDREIRA, L.C.V.S.F. \& ALMEIDA ABREU, P.A. Serra do Espinhaço Meridional: Paisagens e Ambientes. Belo Horizonte, O Lutador, 2005. 272p. 
SILVA, A.C.; VIDAL TORRADO, P.; MARTINEZ-CORTIZAS, A. \& GARCIA RODEJA, E. Solos do topo da Serra São José (Minas Gerais) e suas relações com o paleoclima no Sudeste do Brasil. R. Bras. Ci. Solo, 28:455-468, 2004.

SILVA, E.B.; SILVA, A.C.; GRAZZIOTTI, P.H.; FARNEZI, M.M.M.; FERREIRA, C.A.; COSTA, H.A.O. \& HORAK, I. Comparação de métodos para estimar a acidez potencial mediante determinação do $\mathrm{pH}$ SMP em organossolos da Serra do Espinhaço Meridional. Brasil. R. Bras. Ci. Solo, 32:2007-2013, 2008.

SILVA, I.R. \& MENDONÇA, E.S. Matéria orgânica do solo. In: NOVAIS, R.F.; ALVAREZ, V.H.; BARROS, N.F.; FONTES, R.L.F.; CANTARUTTI, R.B. \& NEVES, J.C.L. Fertilidade do solo. Viçosa, MG, Sociedade Brasileira de Ciência do Solo, 2007.p.374-470.

SWIFT, R.S. Organic matter characterization. In: SPARKS, D.L., ed. Methods of soil analysis chemical methods. Madison, Soil Science Society America/America Society of Agronomy, 1996. p.1011-1069. Part 3. (Book Series, 5)
TOLONEN, K. Peat as a renewable resource: Long-term accumulation rates in North European mires. In: INTERNATIONAL SYMPOSIUM CLASSIFICATION OF PEAT AND PEATLANDS, 1979, Hyytiala. Proceedings... Helsinki, International Peat Society, 1979. p.282-296.

UNITED STATES DEPARTMENT OF AGRICULTURE. Natural Resources Conservation Service. Soil Survey Staff. Soil taxonomy: a basic system of soil classification for making and interpreting soil surveys. 2.ed. Washington D.C., 1999. 870p. (USDA. Agriculture Handbook, 436)

VALLADARES, G.S. Caracterização de Organossolos, auxílio à sua classificação. Seropédica, Universidade Federal Rural do Rio de Janeiro, 2003. 142p. (Tese de Doutorado)

VANCE, E. D.; BROOKES, P. C. \& JEKINSON, D.S. An extration method for measuring soil microbial biomass carbon. Soil Biol. Biochem., 22:703-707, 1987. 